\title{
EVOLUTION OF THE FUCACEAE (PHAEOPHYCEAE) INFERRED FROM nrDNA-ITS ${ }^{1}$
}

\author{
Ester A. Serrão, ${ }^{2}$ Lawrence A. Alice, ${ }^{3}$ and Susan H. Brawley ${ }^{4}$ \\ Department of Plant Biology and Pathology, University of Maine, 5722 Deering Hall, Orono, Maine 04469-5722
}

Sequences of the internal transcribed spacer region (ITS-1, 5.8S, and ITS-2) of nuclear ribosomal DNA were obtained from 16 species representing all six genera of Fucaceae (Ascophyllum, Fucus, Hesperophycus, Pelvetia, Pelvetiopsis, and Xiphophora) plus one outgroup (Hormosira). Parsimony analysis indicated that the family Fucaceae is monophyletic and that the northern hemisphere taxa are highly divergent from the only southern hemisphere genus, Xiphophora. The genus Pelvetia is not monophyletic because the European $P$. canaliculata is more closely related to Fucus, Hesperophycus, and Pelvetiopsis than to other Pelvetia species. We establish Silvetia, gen. nov. and transfer the 3 Pacific species of Pelvetia to the new genus. Fucus is monophyletic and not ancestral in the Fucaceae. The ITS sequences identified two strongly supported lineages within Fucus, one with $F$. serratus sister to the clade containing $F$. gardneri, $F$. distichus, and $F$. evanescens and a second including $F$. vesiculosus, $F$. spiralis, $F$. ceranoides, and $F$. virsoides. The ITS was not useful for resolving relationships within each of these clusters and between populations of $\boldsymbol{F}$. vesiculosus. Within-individual variation in ITS sequences is high in Fucus, a derived genus, compared to Ascophyllum, a more ancestral genus. Mapping of the two characters that form the basis of Powell's model for speciation in the Fucaceae showed that 1) number of eggs per oogonium has not followed a gradual reduction and that 2) monoecy/dioecy has changed several times during evolution of this family.

Key index words: Ascophyllum; Fucaceae; Fucus; Hesperophycus; Hormosira; nrDNA internal transcribed spacers; Pelvetia; Pelvetiopsis; phylogeny; Silvetia; Xiphophora

Abbreviations: CTAB, hexadecyl trimethyl ammonium bromide; ITS, internal transcribed spacer; LSU, large subunit; nrDNA, nuclear ribosomal DNA; PCR, polymerase chain reaction; SSU, small subunit

Algae of the family Fucaceae dominate the biomass in the intertidal areas of many cold and warm temperate regions in the northern hemisphere,

\footnotetext{
${ }^{1}$ Received 26 March 1998. Accepted 21 December 1998.

2 Present address and author for reprint requests; Centro de Ciências do Mar-CCMAR, U.C.T.R.A., Universidade do Algarve, Campus de Gambelas, 8000 Faro, Portugal; e-mail eserrao@ualg.pt.

${ }^{3}$ Present address: Biology Department, Virginia Polytechnic Institute and State University, Blacksburg, Virginia 24061.

${ }^{4}$ Present address: School of Marine Sciences, University of Maine, 5722 Deering Hall, Orono, Maine 04469-5722.
}

where five genera are recognized: Ascophyllum, Fucus, Hesperophycus, Pelvetia, and Pelvetiopsis. Only one genus, Xiphophora, occurs in the southern hemisphere and is restricted to the Australasian region (Clayton 1984). The causes of this skewed distribution are not understood, especially given that none of the Fucaceae are adapted to warmer water temperatures, which might explain a transequatorial distribution at some stage of their evolution. At least eight species are recognized within the genus Fucus (Powell 1963, Rice and Chapman 1985) and four in Pelvetia (Song et al. 1996).

Evolutionary relationships within the Fucaceae and within the genera Fucus and Pelvetia are unclear and remain controversial (e.g. Niell et al. 1980, Rice and Chapman 1985, Wynne and Magne 1991, Song et al. 1996, Leclerc et al. 1998). Powell (1963) grouped over a hundred species, varieties, and forms of Fucus into just six species and further proposed an evolutionary scheme of the Fucaceae in which great importance was attached to monoecy versus dioecy and the number of viable eggs produced per oogonium. Fucus, which produces eight eggs per oogonium, had been considered the most primitive genus in the Fucaceae (Fritsch 1945), and Powell (1963) proposed that all fucacean genera were derived from Fucus, with a progressive reduction in the number of eggs that develop from the eight nuclei of the oogonium (four in Ascophyllum, two in Pelvetia, and one in Pelvetiopsis and Hesperophycus). The hypothetical ancestral Fucus would have given rise to a dioecious and a monoecious lineage (Fig. 1). Even though Powell (1963) preferred to put many previously described species and varieties of Fucus into synonymy, it is clear that the genus has radiated extensively. A high degree of phenotypic plasticity exists that is often correlated with ecological factors, such as herbivory, salinity, and wave exposure (e.g. Knight and Parke 1950, Niell et al. 1980, Kalvas and Kautsky 1993, Pérez-Ruzafa et al. 1993). This widespread occurrence of poorly defined species could be due to a recent radiation. In addition, species of Fucus can hybridize, as suggested by laboratory studies including cross-fertilizations and/or culture of hybrid individuals (Thuret 1854, Williams 1899, Kniep 1925, Burrows and Lodge 1953, Bolwell et al. 1977, Edwards et al. 1997). Hybridization is also one possible explanation for the natural occurrence of individuals with intermediate morphologies (Sauvageau 1909, Gard 1910, Stomps, 1911, Kniep 1925, Burrows and Lodge 1951, Scott and Hardy 1994).

Although Powell's (1963) model of evolutionary 


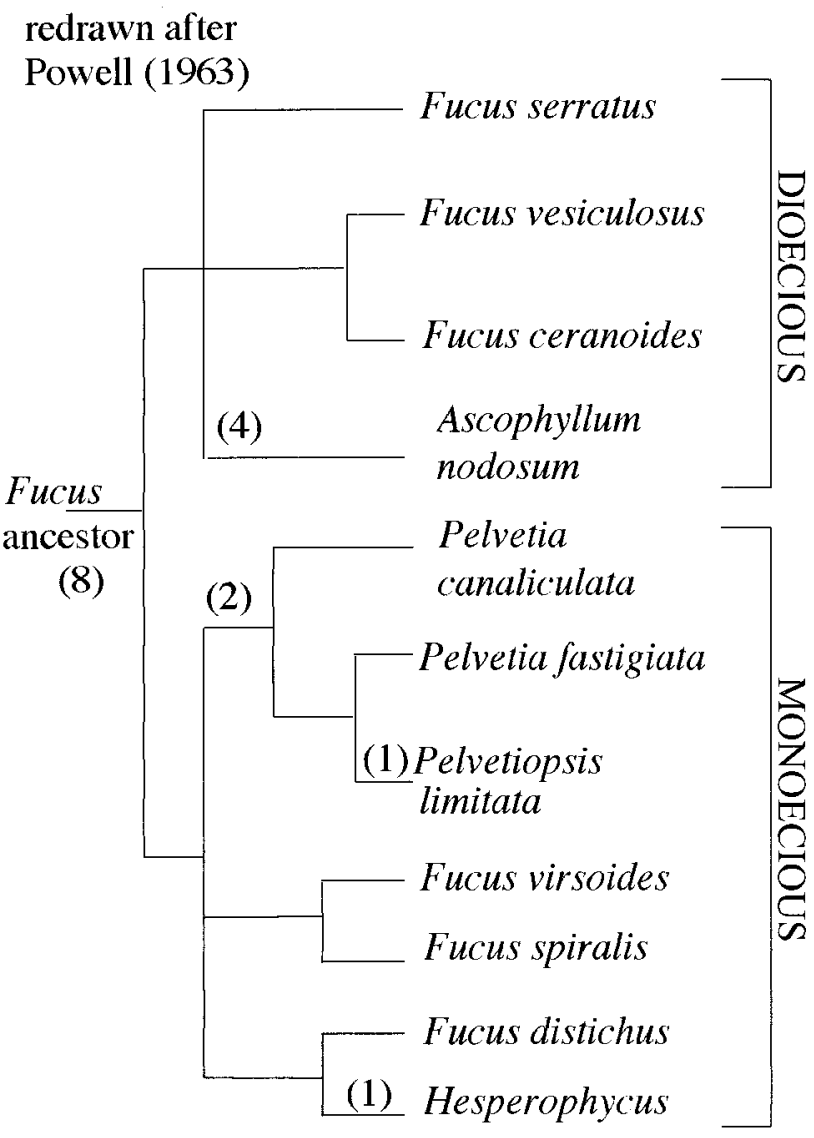

FIG. 1. Speciation of the northern hemisphere Fucaceae, as proposed by Powell (1963) and represented here in cladogram format. This hypothesis was based on the characters 1) monoecy/ dioecy and 2) the number of eggs produced per oogonium (this is indicated between brackets at the branches where each state originated). Following the initial divergence of the dioecious and monoecious clades, we represented a trichotomy in each clade because Powell did not discuss the divergence hierarchy at this level.

relationships in Fucaceae has been widely followed, it is phylogenetically invalid because the proposed divergence of Fucaceae into monoecious and dioecious lineages would prevent Fucus from being monophyletic. This leads to two mutually exclusive questions: 1) is Fucus monophyletic, or 2) are the Fucaceae divided into two lineages corresponding to monoecy and dioecy? The evolutionary relationships within the genus Pelvetia are also controversial, as earlier suggestions (Serrão 1996, Serrão and Brawley 1997) and recent work by Lee et al. (1998) have suggested that $P$. canaliculata might form a separate lineage distinct from the Pacific Pelvetia.

The nuclear rDNA internal transcribed spacers (ITS-1 and ITS-2) are used widely in phylogenetic studies at the species level (reviews by Hamby and Zimmer 1992, Baldwin et al. 1995). They have been used extensively in algae (e.g. Kooistra et al. 1992, Coleman et al. 1994, Goff et al. 1994, Bakker et al. 1995a, b, van Oppen et al. 1995), brown algae in particular (Saunders and Druehl 1993, van Oppen et al. 1993, Peters et al. 1997, Stache-Craine et al. 1997), and most recently in Fucus (Leclerc et al. 1998).

In this study, we use ITS sequences to investigate phylogenetic relationships among the six genera of the Fucaceae as well as species relationships within Fucus and Pelvetia. We also examine Powell's hypothesis for the evolution of monoecy/dioecy and number of eggs per oogonium in the Fucaceae in light of our ITS-based phylogeny.

\section{MATERIALS AND METHODS}

Sample material. Most species of Fucus occur in the Atlantic except $F$. gardneri, a Pacific endemic, and $F$. virsoides, an endemic of the Mediterranean Sea. In addition to their Atlantic distributions, $F$. spiralis occurs in the eastern Pacific and F. evanescens in the western Pacific. All species of Pelvetia occur in the Pacific except Pelvetia canaliculata. Ascophyllum is monotypic and occurs exclusively in the Atlantic. Pelvetiopsis and Hesperophycus are also monotypic, and they are found exclusively in the Pacific. Xiphophora occurs in the Australasian region and is the only genus from the southern hemisphere in the Fucaceae. All currently recognized species of each Fucaceae genus were sampled (Table 1) with the exception of Xiphophora gladiata, which occurs only in Tasmania. The ITS sequences of each species were determined from several locations when possible. Voucher specimens from most of these locations were deposited in the University of Maine's herbarium.

When it was possible to obtain reproductive material, sperm were used for the DNA extractions because they yielded DNA in greater quantities and better quality (i.e. they have lower polysaccharide contamination and are free of endophytes, such as the fungus that occurs in A. nodosum and $P$. canaliculata). To obtain uncontaminated sperm cells, receptacles were washed with distilled water and placed in petri dishes under the light. As they dried, antheridia (containing sperm) were expelled through the pore of each conceptacle in an orange, mucilaginous mass. A few of these were picked from just outside the pore of each conceptacle with a sterile needle at a dissecting microscope, frozen in liquid $\mathrm{N}_{2}$, and stored at $-80^{\circ} \mathrm{C}$ until extraction. When it was not possible to obtain fresh sperm cells, vegetative tips from fresh, herbarium, or silica-gel-dried material were used. Material from the Baltic Sea was ground in the CTAB extraction buffer (see following discussion) and stored at room temperature for approximately 1 month before extraction.

DNA extraction. DNA was extracted using a CTAB method (modified after Doyle and Doyle 1987). Antheridia were ground in microcentrifuge tubes with $2 \mathrm{X}$ CTAB buffer $(2 \% \mathrm{CTAB}, 1.4 \mathrm{M}$ $\mathrm{NaCl}, 0.2 \%$-mercaptoethanol, $20 \mathrm{mM}$ EDTA, $100 \mathrm{mM}$ Tris $\mathrm{HCl}$ $\mathrm{pH} 8,1 \%$ PVP-40), and vegetative tips were ground in liquid $\mathrm{N}_{2}$ before adding the CTAB buffer. The samples were incubated with 2X CTAB buffer and proteinase $\mathrm{K}$ at $60^{\circ} \mathrm{C}$ for $\geq 1 \mathrm{~h}$ with frequent agitation, followed by two purification steps with chloroform:isoamyl alcohol and precipitation with isopropanol. RNA in the redissolved pellet was digested and RNAse removed with phenol plus chloroform:isoamyl alcohol followed by an overnight precipitation with $100 \%$ ethanol and ammonium acetate. DNA quality and quantity in the redissolved pellet were assessed on agarose gels and microfluorometrically.

PCR amplification. The ITS region of each sample was symmetrically amplified by PCR either with the primers ITS5 and ITS4 (White et al. 1990; Fig. 2) or with F5 and F4 (Fig. 2), which we specifically designed for Fucus from a sequence for the SSU of rDNA available for F. gardneri at GenBank (X53987) and on our own sequences for the $5^{\prime}$ end of the LSU of Fucus. Amplification conditions were $1 \mathrm{X}$ buffer II, $1.9 \mathrm{mM} \mathrm{MgCl}, 0.2 \mathrm{mM} / \mathrm{dNTP}, 0.3$ $\mu \mathrm{M} /$ primer, $1.25 \mathrm{U}$ of Stoffel Fragment or AmpliTaq (Perkin Elmer, Norwalk, Connecticut), and $2 \mathrm{ng}$ of genomic DNA per 25$\mu \mathrm{L}$ reaction. The PCR parameters were $94^{\circ} \mathrm{C}$ for $5 \mathrm{~min}, 45$ cycles of $97^{\circ} \mathrm{C}$ for $1 \mathrm{~min}, 48^{\circ} \mathrm{C}$ for $2 \mathrm{~min}$, and $72^{\circ} \mathrm{C}$ for $3 \mathrm{~min}$, followed by a final extension step at $72^{\circ} \mathrm{C}$ for $15 \mathrm{~min}$. These conditions 
TABLE 1. List of sampled species of the Fucaceae used to sequence the ITS region. In addition to these, the five ITS sequences from Leclerc et al. (1998) were also used in the global analyses. GenBank accession numbers in boldface represent the sequences selected for the more extended analyses. Multiple numbers for the same geographic region represent ITS sequences determined from a single individual, except in the case of Hesperophycus californicus, for which the first two sequences are from one individual and the other two sequences are from another individual.

\begin{tabular}{|c|c|c|c|}
\hline Species & Geographic origin & $\begin{array}{c}\text { GenBank } \\
\text { accession number }\end{array}$ & $\begin{array}{l}\text { University } \\
\text { of Maine } \\
\text { Herbarium } \\
\text { accession } \\
\text { number }\end{array}$ \\
\hline \multirow{8}{*}{ Ascophyllum nodosum (Linnaeus) Le Jolis } & Isle of Man (Port St. Mary Ledges) & AF102971 & - \\
\hline & Maine coast (Schoodic Point, Acadia National Park) & $\begin{array}{l}\text { AF102961, AF102962, } \\
\text { AF102963 }\end{array}$ & UMAL278 \\
\hline & Maine estuary (Penobscot River, near Bucksport) & AF102964 & UMAL279a \\
\hline & Massachussetts (Woods Hole) & AF102965, AF102966 & UMAL271 \\
\hline & Northern Portugal (Viana do Castelo, Minho) & AF102969 & UMAL274 \\
\hline & Norway (Sotra, near Bergen) & AF102967 & UMAL258 \\
\hline & Western Ireland (Galway) & AF102968 & - \\
\hline & White Sea (Ivanov Navolok, Russia) & AF102970 & UMAL256 \\
\hline Fucus ceranoides Linnaeus & Isle of Man (Castletown Harbour) & AF102903 & UMAL266 \\
\hline \multirow[t]{2}{*}{ Fucus distichus Linnaeus } & Maine coast (Chamberlain) & AF102935 & UMAL277a \\
\hline & White Sea (Ivanov Navolok, Russia) & AF102936 & UMAL272 \\
\hline \multirow{3}{*}{ Fucus evanescens C. Agardh } & Japan (Muroran, Hokkaido) & AF102937 & - \\
\hline & Maine coast (Schoodic Point, Acadia National Park) & AF102938 & UMAL276 ${ }^{\mathrm{a}}$ \\
\hline & White Sea (Ivanov Navolok, Russia) & AF102939 & UMAL252 \\
\hline \multirow{2}{*}{ Fucus gardneri P.C. Silva } & California (Pigeon Point, San Mateo) & AF102940 & UMAL265 \\
\hline & Washington (San Juan Island) & AF102941 & UMAL259 \\
\hline \multirow[t]{2}{*}{ Fucus serratus Linnaeus } & Nova Scotia (Lunenburg Cove) & $\begin{array}{l}\text { AF102943, AF102944, } \\
\quad \text { AF102945 }\end{array}$ & - \\
\hline & Norway (Sotra, near Bergen) & AF102942 & UMAL260 \\
\hline \multirow[t]{5}{*}{ Fucus spiralis Linnaeus } & Canary Islands (Punta de Galdar, Gran Canaria) & AF102904 & UMAL268 \\
\hline & Maine coast (Schoodic Point, Acadia National Park) & AF102905-6 & UMAL280a \\
\hline & Northern Portugal (Viana do Castelo, Minho) & AF102907 & UMAL262 \\
\hline & Oregon (Boiler Bay) & AF102908 & - \\
\hline & Washington (San Juan Island) & AF102909 & UMAL269 \\
\hline \multirow[t]{10}{*}{ Fucus vesiculosus Linnaeus } & $\begin{array}{l}\text { Algarve, Portugal (Ria Formosa Natural Park, near } \\
\text { Faro) }\end{array}$ & AF102910 & UMAL257 \\
\hline & Central Baltic Sea (Askö, near Stockholm) & $\begin{array}{l}\text { AF102911, AF102912, } \\
\text { AF102913 }\end{array}$ & - \\
\hline & Isle of Man (Port St. Mary) & AF102919-21 & UMAL261 \\
\hline & Maine estuary (Penobscot river, near Bucksport) & AF102926-7 & UMAL281 \\
\hline & Maine coast (Schoodic Point, Acadia National Park) & AF102922 & UMAL282 \\
\hline & Northern Baltic Sea (Drivan, near Umeå) & AF102914-8 & UMAL255 \\
\hline & Northern Portugal (Viana do Castelo, Minho) & AF102925 & UMAL283 \\
\hline & Skagerrak (Tjärnö, Swedish west coast) & AF102928-9 & - \\
\hline & Southern Norway (Sotra, near Bergen) & AF102923-4 & UMAL253 \\
\hline & White Sea (Ivanov Navolok, Russia) & AF102930-2 & UMAL273 \\
\hline \multirow[t]{2}{*}{ Fucus virsoides J. Agardh } & Mediterranean (Trieste, Adriatic Sea) & AF102933 & - \\
\hline & Mediterranean (Venice, Adriatic Sea) & AF102934 & - \\
\hline Hesperophycus californicus P.C. Silva & $\begin{array}{l}\text { California (between Lovers' Point and Point Piños, } \\
\text { Monterey) }\end{array}$ & $\begin{array}{l}\text { AF102946, AF102947, } \\
\text { AF102948, AF102949, } \\
\text { AF102950 }\end{array}$ & $\begin{array}{l}\text { UMAL251, } \\
\text { UMAL250 }\end{array}$ \\
\hline Pelvetia babingtonii (Harvey) De Toni & Japan (Muroran, Hokkaido) & AF102957 & UMAL254 \\
\hline \multirow{3}{*}{$\begin{array}{l}\text { Pelvetia canaliculata (Linnaeus) Decaisne } \\
\text { et Thuret }\end{array}$} & Isle of Man (Port St. Mary, Chapel Bay) & AF102955 & UMAL264 \\
\hline & Northern Portugal (Viana do Castelo, Minho) & AF102954 & UMAL263 \\
\hline & Southern Norway (Sotra, near Bergen) & AF102953 & UMAL267 \\
\hline Pelvetia compressa (J. Agardh) De Toni & California (Pigeon Point, San Mateo) & AF102956 & UMAL275a \\
\hline Pelvetia siliquosa Tseng et C.F. Chang & China (Shandong Peninsula) & $\begin{array}{l}\text { AF102958, AF102959, } \\
\text { AF102960 }\end{array}$ & - \\
\hline \multirow[t]{2}{*}{ Pelvetiopsis limitata (Setchell) Gardner } & California (Pigeon Point, San Mateo) & AF102951 & UMAL270 \\
\hline & Oregon (Boiler Bay) & AF102952 & - \\
\hline $\begin{array}{l}\text { Xiphophora chondrophylla (R. Brown ex } \\
\text { Turner) Montagne ex Harvey }\end{array}$ & Southern Australia (Flinders) & AF102972 & - \\
\hline $\begin{array}{l}\text { Hormosira banksii (Turner) Decaisne } \\
\quad \text { (= outgroup) }\end{array}$ & Southern Australia (Sorrento) & $\begin{array}{l}\text { AF102973, AF102974, } \\
\text { AF102975, AF102976, } \\
\text { AF102977, AF102978, } \\
\text { AF102979 }\end{array}$ & - \\
\hline
\end{tabular}

\footnotetext{
a A morphologically similar specimen from the same site.
} 


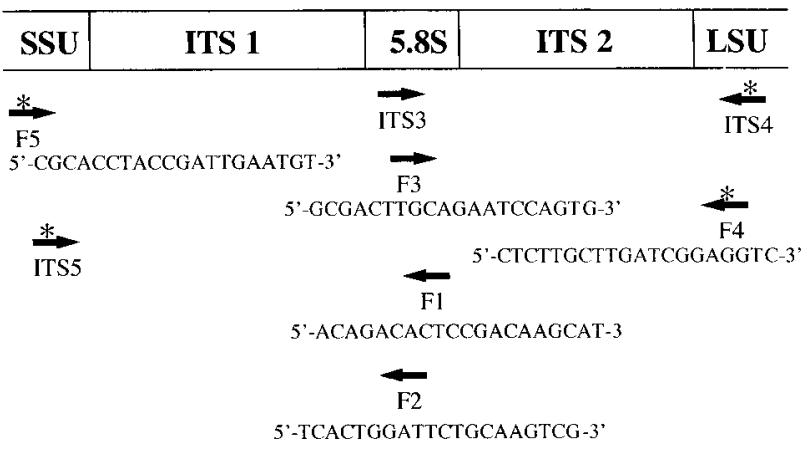

FIG. 2. The nrDNA ITS region showing the relative position of the $3^{\prime}$ end of the SSU gene, ITS-1, the 5.8S gene, ITS-2, the $5^{\prime}$ end of the LSU gene, and the location of the primers used. Sequences for primers F1 through F5 are shown; primers ITS3 and ITS4 are from White et al. (1990). Primers not to scale. ${ }^{*}=$ primers used in PCR amplification.

were optimized to amplify preferentially the ITS region from the Fucaceae over that from endophytes, which was always smaller.

PCR products were electrophoresed in agarose gels and run long enough to isolate the target 1000-1100-bp ITS band of the Fucaceae from other, always smaller fragments that were present in some cases, such as the ITS region of Mycosphaerella ascophylli Le Jolis, an endophytic fungus in Ascophyllum nodosum and Pelvetia canaliculata. Sequencing of these smaller bands followed by GenBank searches confirmed that they belonged to the genus Mycosphaerella (data not shown), whereas GenBank searches matching the sequences of the 1000-1100-bp products confirmed that these belonged to the Phaeophyceae. The target bands were cut under UV light, and the agarose was digested with $\beta$-agarase by the manufacturer's instructions (FMC, Rockville, ME). These products were either cloned or used for the sequencing reactions without further purification.

Cloning. To determine the extent of intraindividual polymorphism in some taxa and/or populations, the whole ITS region was cloned (TOPO TA cloning kit, Invitrogen Corp., La Jolla, Cailfornia) following the manufacturer's instructions, and plasmid DNA from each recombinant colony was extracted using alkaline lysis minipreps with PEG precipitation (Applied Biosystems Inc., User Bulletin \#18).

Sequencing. The ITS region of one to five individuals of each species or population was sequenced in both directions using the Sanger dideoxy chain termination method for cycle sequencing with dye-labeled terminators (Perkin Elmer) on an ABI 373 automated sequencer (Applied Biosystems, Foster City, California). For direct sequencing, the primers used to sequence the ITS-2 region were ITS3 or F3 and ITS4 or F4 (Fig. 2). The primers used to sequence the ITS-1 region were ITS5 or F5, F2, or in a few cases F1. Where the whole ITS region had been cloned, it was possible to fully sequence from the $3^{\prime}$ end of the SSU gene to the $5^{\prime}$ end of the LSU gene in both directions (over $1000 \mathrm{bp}$ ) using universal primers in the vector.

Alignment. The chromatogram output for each sample was edited using the software Sequence Navigator 1.0.1 (Applied Biosystems Inc.), and the sequences were manually aligned. To determine the ITS boundaries for the Fucaceae, the flanking sequences of ITS-1 and ITS-2 were aligned with all ITS sequences listed in GenBank that include the flanking sequence for the SSU, the $5.8 \mathrm{~S}$, and the LSU genes. These sequences represent a wide range of organisms, including other protists, animals, fungi, and plants. The limits of ITS-1 and ITS-2 varied among all these sequences; thus, the positions at which a sharp change occurs from a sequence that is conserved across all taxa to a sequence that becomes variable (and vice versa for the $3^{\prime}$ ends of the ITS regions) are those most likely to be the real boundaries between the rRNA genes and the spacers, and these were considered as such in this study. Of the 82 sequences used, 77 were determined in this study from several geographic regions and in some cases from several clones within individuals. This alignment is available at GenBank. An additional five sequences from Leclerc et al. (1998) from Roscoff, Brittany, were included in this study, but we considered $F$. lutarius to be a form of F. vesiculosus (as in Powell 1963).

Outgroup selection. The sister group to the Fucaceae is unknown because different morphological characteristics suggest different evolutionary patterns. Our choice was based on the suggestion by Clayton (1984) that the families of Fucales radiated from Australasia because all but one family of Fucales occur in Australasia and all are represented by species with primitive characteristics. In the Fucaceae, Xiphophora is the Australasian genus with primitive characteristics. Hormosira is an Australasian taxon that shares unique characteristics with Xiphophora (see Clayton 1984) and was thus used as outgroup. In addition to this, we also obtained full sequences (data not shown) for other Fucales: Cystoseira, Bifurcar$i a$, and Cystosphaera (the latter was once included in the Fucaceae), but these were almost unalignable.

Phylogenetic analyses. Given the large number of sequences and poor resolution within species, it was impossible within reasonable computational time to execute a heuristic search to completion with all sequences. For this reason, a bootstrap (1000 replicates) consensus tree was determined for 82 Fucaceae ITS sequences using the "fast" stepwise addition method, as implemented in PAUP 4.0b1 (Swofford 1998), to select representative sequences for a more comprehensive analysis. The basal-most sequence was selected from each species or each clade of poorly resolved species because this sequence is the one most likely to have the plesiomorphic states as opposed to derived apomorphic sequences in terminal clades. Character state changes were all weighted equally. Polymorphisms were treated as uncertain, and insertions/deletions (indels) were coded as missing data to avoid including them as if they were many independent events while still retaining the information about substitutions in other taxa in the indel regions. In a separate analysis, indels were assumed to be single evolutionary events and were given the same weight as nucleotide substitutions by coding them in a separate matrix as binary characters. Large indels and those from regions where these tend to occur frequently by strand slippage (e.g. microsatellite regions) were not included in the analysis because they were unlikely to be the result of single events and positional homology could not be accurately determined.

Phylogenetic inferences, using the selected subset of sequences, used three different optimality criteria: maximum parsimony, maximum likelihood, and neighbor joining. Maximum-likelihood analysis was based on the Hasegawa-Kishino-Yano model. Neighbor-joining analyses were performed with three distance models: uncorrected distances, Jukes-Cantor, and Kimura 2-parameter. Inferences based on Fitch parsimony used the Branch-and-Bound algorithm, which guarantees finding the shortest trees (Hillis et al. 1993). All analyses were performed with PAUP 4.0b1. To test for phylogenetic signal in the data, we determined the index of skewness (g1) of the distribution of tree lengths of 100,000 random trees using PAUP and compared it to the critical value for 15 taxa and 500 variable characters in Hillis and Huelsenbeck (1992). Confidence limits of individual clades were estimated by bootstrap analysis (Felsenstein 1985) with 100,000 replicates, and decay analysis (Bremer 1988, Donoghue et al. 1992) was performed with AutoDecay 3.0 (Eriksson and Wikstrom 1996) and the reverse constraint option in PAUP. Two primary characters used in Powell's classification were mapped onto the ITS tree using MacClade 3.0 (Maddison and Maddison 1992).

\section{RESULTS}

ITS properties and alignment. In the Fucaceae, the length of ITS-1 varied between 401 and 515 bp and that of ITS-2 between 322 and 409 bp (Table 3). We were unable to obtain the ITS-2 sequence from $X$. chondrophylla. These length values are not comparable to those published for Fucus and other brown algae (Saunders and Druehl 1993, van Oppen et al. 
TABLE 2. Length and GC content of ITS-1 and ITS-2 region in the Fucaceae and Hormosira banksii (n.d. = not determined).

\begin{tabular}{|c|c|c|c|c|}
\hline \multirow[b]{2}{*}{ Taxon } & \multicolumn{2}{|c|}{ "ITS-1 } & \multicolumn{2}{|c|}{ ITS-2 } \\
\hline & Length (bp) & GC (\%) & Length (bp) & GC (\%) \\
\hline Ascophyllum nodosum & $409-410$ & $51-52$ & $322-331$ & $58-60$ \\
\hline Hesperophycus californicus & 515 & 51 & 392 & 51 \\
\hline Fucus ceranoides & 477 & 52 & 353 & 55 \\
\hline Fucus distichus & $460-461$ & $49-52$ & 356 & $51-55$ \\
\hline Fucus evanescens & $461-464$ & 49 & $356-357$ & 55 \\
\hline Fucus gardneri & 461 & 49 & 356 & 55 \\
\hline Fucus serratus & $464-472$ & $49-50$ & 353 & $55-56$ \\
\hline Fucus spiralis & $469-470$ & $49-50$ & 353 & $54-57$ \\
\hline Fucus vesiculosus & $462-486$ & 50 & $349-353$ & 55 \\
\hline Fucus virsoides & $483-485$ & 50 & 353 & 54 \\
\hline Pelvetia babingtonii & 401 & 47 & 409 & 60 \\
\hline Pelvetia canaliculata & 414 & 53 & 383 & 58 \\
\hline Pelvetia compressa & 404 & 48 & 398 & 60 \\
\hline Pelvetia siliquosa & 401 & 47 & 385 & 60 \\
\hline Pelvetiopsis limitata & 486 & 51 & $385-387$ & 56 \\
\hline Xiphophora chondrophylla & 511 & 46 & n.d. & n.d. \\
\hline Mean \pm SE for Fucaceae & $456.1 \pm 9.6$ & $49.6 \pm 0.5$ & $367.4 \pm 5.9$ & $56.1 \pm 0.7$ \\
\hline Hormosira banksii (= outgroup) & $454-456$ & 50 & $274-285$ & 52 \\
\hline
\end{tabular}

1993, Peters et al. 1997, Stache-Craine et al. 1997, Leclerc et al. 1998) because the boundaries of the ITS regions are not all coincident, as explained in the Materials and Methods section. Samples amplified with primer F5 included 125-129 bp more in the SSU gene than those amplified with the primer ITS5. An additional 150-152 bp corresponding to the $5.8 \mathrm{~S}$ gene and $15 \mathrm{bp}$ of the $5^{\prime}$ end of the LSU gene were also included. The GC content of ITS-1 in the Fucaceae is $46 \%-53 \%$, and it is $51 \%-60 \%$ in ITS-2 (Table 2).

Alignment of the DNA sequences required adding numerous gaps. Sequence variation within the Fucaceae is mostly due to nucleotide substitutions, although several small indels and some large indels can be found. Another source of sequence divergence is length variation due to stretches of short repeats that occur at the $3^{\prime}$ end of ITS1 or ITS2 in all the Fucaceae (except $P$. canaliculata) and in Hormosira. Aligned sequences provided a total of 1605 characters, including gaps, from which 564 were variable (excluding indels) and 342 potentially parsimony informative.

Intra- and interspecific divergence. Pairwise divergence in the ITS region (i.e. ITS-1 and ITS-2 combined, excluding the gene sequences) of the Fuca- ceae from the northern hemisphere ranged from $4.2 \%$ to $20.9 \%$ between genera (Table 3 ). These in turn have diverged over twice as much from the southern hemisphere genus Xiphophora (36.5\%$45.2 \%$, Table 3 ) in the ITS regions. Within Pelvetia, one species is strikingly different from the others: $P$. canaliculata (Atlantic) shows 12.9\%-13.3\% (Table 3) divergence from the Pacific species of Pelvetia, whereas these differ from each other by only $0.8 \%-$ $2 \%$ in their ITS regions. In Fucus, the divergence between ITS sequences from different geographic regions is in many cases in the same order of magnitude as the divergence between different species (Table 4). Considerable within-individual variability (Table 4) was detected in $F$. vesiculosus, the species of Fucus for which more within-individual sequences were obtained, from several individuals from different geographic regions. In this species, most ITS sequences differed by about 1\%-2\% from the other ITS sequences determined from the same individual, and no two identical ITS sequences were found in a single individual of Fucus. This is in contrast to low (Table 4) within-individual variability in $A$. nodosum.

Phylogenetic analyses. The phylogenetic tree obtained including all sequences (Fig. 3), shows three

TABLE 3. Ranges of pairwise distances (\%) between the genera for ITS-1 and ITS-2 combined (excluding the portions of the alignment that correspond to rRNA genes). The species of Pacific Pelvetia are presented separately from the Atlantic Pelvetia canaliculata to show the high divergence between them and because their distances to Ascophyllum in particular are considerably distinct.

\begin{tabular}{lcccccc}
\hline \hline & \multicolumn{5}{c}{ Ranges of pairwise distances (\%) } \\
\cline { 2 - 7 } Genus & Ascophyllum & Pelvetia (Pacific) & Pelvetia (Atlantic) & Pelvetiopsis & Hesperophycus & Fucus \\
\hline Xiphophora & $36.5-36.9$ & $37.2-38.1$ & 41.2 & 44.0 & $44.9-45.2$ & $41.0-43.8$ \\
Ascophyllum & - & $10.2-11.6$ & $15.0-15.6$ & $16.6-17.3$ & $17.3-18.3$ & $17.6-20.9$ \\
Pelvetia (Pacific) & - & - & $12.9-13.3$ & $14.4-15.3$ & $15.5-16.6$ & $15.0-18.4$ \\
Pelvetia (Atlantic) & & - & $14.7-14.8$ & $15.1-15.5$ & $15.4-18.0$ \\
Pelvetiopsis & & & - & $4.2-4.6$ & $10.1-13.6$ \\
Hesperophycus & & & & - & $-11.5-15.0$ \\
\hline
\end{tabular}


TABLE 4. Ranges of pairwise distances (\%) in the ITS region between 1) species of each genus, 2) geographic regions for each species, 3) individuals in each region, and 4) ITS fragments cloned from single individuals. Sequences from Leclerc et al. (1998) were included in this analysis, but we considered Fucus lutarius to be a form of Fucus vesiculosus (as in Powell 1963). Xiphophora is not included in the table because only one sequence was determined. ( $\mathrm{n}=$ number of species, regions/species, individuals/region or clones/individual involved, respectively, where more than one were determined; n.a. = not applicable; n.d. = not determined).

\begin{tabular}{lcccc}
\hline \hline \multicolumn{1}{c}{ Genus } & Between species & $\begin{array}{c}\text { Between regions } \\
\text { (geographic) }\end{array}$ & Within regions & Within individuals \\
\hline Ascophyllum & $\mathrm{n} . \mathrm{a}$. & $0.0-2.2(\mathrm{n}=9)$ & $\mathrm{n} . \mathrm{d}$. & $0.0-0.2(\mathrm{n}=2-3)$ \\
Fucus & $0.1-7.2(\mathrm{n}=8)$ & $0.0-5.6(\mathrm{n}=2-11)$ & $0.3(\mathrm{n}=2)$ & $0.1-2.6(\mathrm{n}=2-5)$ \\
Hesperophycus & n.a. & n.d. & $0.2-0.3(\mathrm{n}=2)$ & $0.0-0.5(\mathrm{n}=2-3)$ \\
Pelvetia & $0.8-13.3(\mathrm{n}=4)$ & $0.0(\mathrm{n}=2)$ & n.d. & $0.0(\mathrm{n}=3)$ \\
Pelvetiopsis & n.a. & $0.2(\mathrm{n}=2)$ & n.d. & n.d. \\
Hormosira & n.a. & n.d. & n.d. & $0.0-0.8(\mathrm{n}=7)$ \\
\hline
\end{tabular}

well-supported clades of Fucus, but the only clearly monophyletic species in this genus is $F$. serratus. The ITS sequences are not useful to resolve most relationships between the species within each of these two clusters. Fucus serratus is a sister group to a clade containing $F$. gardneri, $F$. distichus, and $F$. evanescens, none of which appears to be monophyletic, and the relationships within the clade containing $F$. vesiculosus, $F$. spiralis, $F$. virsoides, and $F$. ceranoides are not resolved. Thus, the basal-most sequence for $F$. serratus was selected for further analyses, and the remaining Fucus species were represented by a sequence from only one species from each of the other two clades. The same tree topology was obtained if each of the selected sequences was replaced by any other sequence from its clade or by the two most divergent ones in the clade.

The phylogenetic analyses based on the reduced data set yielded one most parsimonious tree of length 768 (Fig. 4), and this was consistent with the tree obtained with all sequences (Fig. 3). The distribution of tree lengths is significantly skewed to the left $(\mathrm{g} 1=-1.26)$, indicating that the data have phylogenetic signal (Hillis 1991, Hillis and Huelsenbeck 1992). The data show low homoplasy, as indicated by a high consistency index $(0.90)$ and retention index (0.89). The ITS tree reveals several clades, most of which are well supported by high bootstrap and decay values (Fig. 4). The data support the Fucaceae as a monophyletic group. In particular, the inclusion of the only southern hemisphere genus of this family, Xiphophora, in the same clade as the other Fucaceae is well supported (Fig. 4 ). The results were identical when the analysis was performed with most indels coded as binary (presence/absence) characters. Maximum-likelihood and neighbor-joining analyses also resulted in the same tree topology as with parsimony, the only exception being the clade with the three Pacific Pelvetia, which collapses into an unresolved trichotomy when either the Kimura 2-parameter or the Jukes-Cantor model is used.

Within the Fucaceae of the northern hemisphere, A. nodosum is sister to all other genera (Fig. 4). Pelvetia is not monophyletic because its Atlantic species, $P$. canaliculata, shares a common ancestor with the genera Hesperophycus, Pelvetiopsis, and Fucus, thus being more closely related to these than to the other Pelvetia. Imposing a constraint tree to force monophyly of Pelvetia adds 13 steps to the most parsimonious tree. However, the Pacific species of Pelvetia ( $P$. babingtonii, $P$. compressa, and $P$. siliquosa) are monophyletic, as is Fucus. All clades are well supported except the node that separates $A$. nodosum from all other northern Fucaceae. This was an unresolved node when all sequences were included in the bootstrap analysis (Fig. 3); the alternative possibility would be uniting $A$. nodosum with the Pacific Pelvetia in a monophyletic clade.

\section{DISCUSSION}

The Fucaceae appear monophyletic, although Xiphophora, the only southern hemisphere genus, is more distantly related to other Fucaceae than all northern Fucaceae are among themselves. Recent studies using rDNA SSU and LSU sequences to study the Fucaceae did not find enough variability to resolve their phylogenetic relationships (Rousseau et al. 1997, Lee et al. 1998). Ascophyllum nodosum appears basal for the northern hemisphere Fucaceae, contradicting suggestions that it might be more related to Fucus than to Pelvetia canaliculata, although these were poorly supported (Rousseau et al. 1997). On the basis of ITS sequences, the Pacific Pelvetia are the closest group to A. nodosum.

Pelvetia does not appear monophyletic. Thus, $P$. canaliculata needs to be recognized as a monotypic genus, creating a monophyletic clade including only the Pacific species of Pelvetia under a new genus (see below), as $P$. canaliculata is the type species for Pelvetia. Additional molecular data support this change (Lee et al. 1998). It is interesting to note that both of the most primitive Fucaceae of the Atlantic Ocean, $A$. nodosum and $P$. canaliculata, share the characteristic of being the hosts of an endophytic species of fungus (Mycosphaerella ascophylli) that is absent in all other Fucaceae (Kohlmeyer and Kohlmeyer 1979).

The idea of an ancestral Fucus that gave rise to all other Fucaceae (Powell 1963) is not consistent with our results or with those of Leclerc et al. (1998), who used ITS sequences to compare five species of Fucus from Brittany and suggested that these were 
FIG. 3. Bootstrap consensus tree, including all ITS sequences for the Fucaceae. Taxa in bold were selected to represent each species or clade in further analyses. Sequences with the same label represent multiple clones from the same individual except in the case of Hesperophycus californicus, for which the first two sequences are from one individual and the other three from anothoutgroup. er one. Hormosira banksii is the

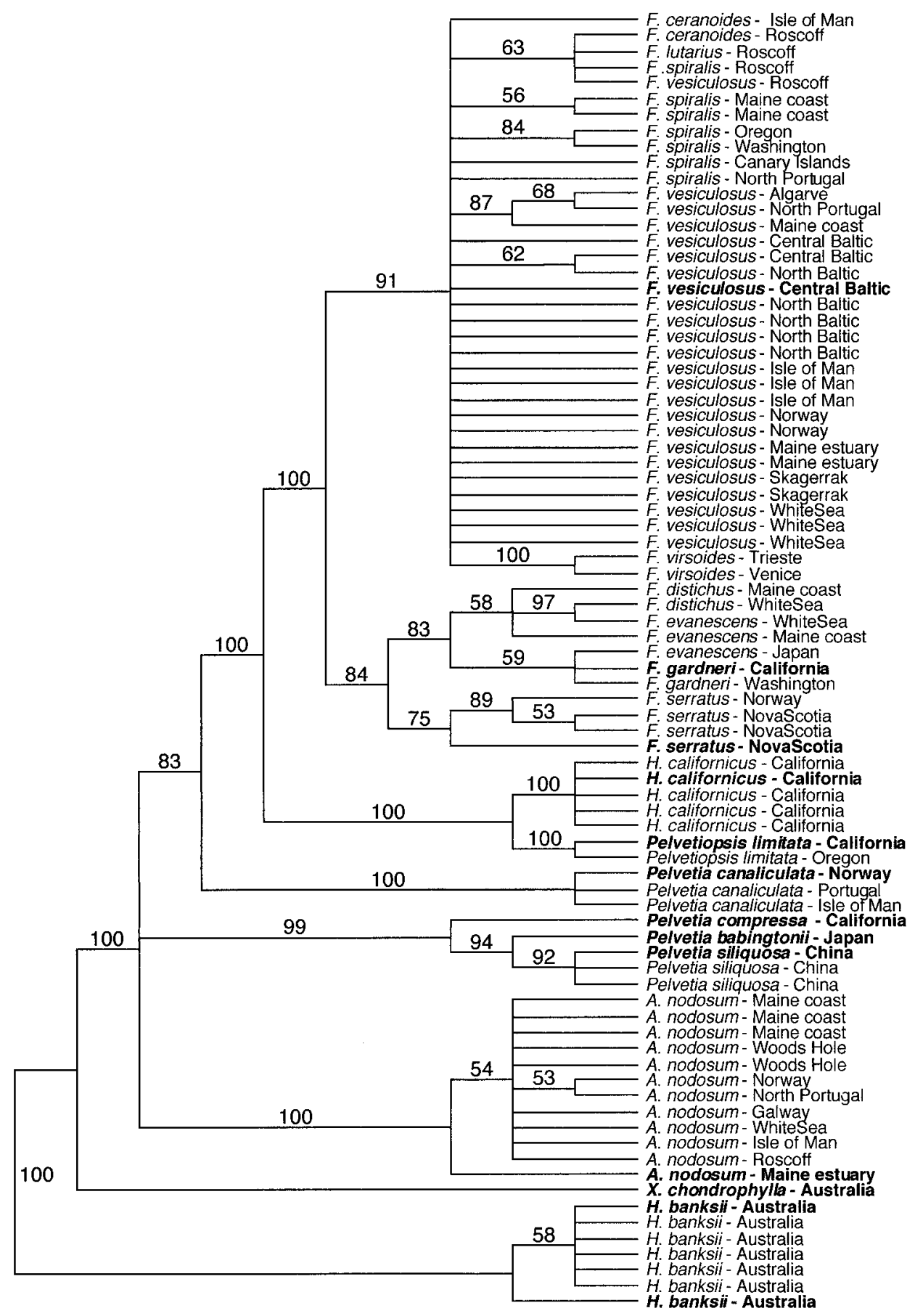

the result of a very recent radiation because sequence variability was very low. However, our results are in agreement with Leclerc et al. (1998) in suggesting a very recent radiation for Fucus, although for opposite reasons: a recent rapid radiation is a possible explanation for the high within-individual variability that we observed in Fucus. Also, our rooted ITS tree for the Fucaceae shows Fucus as the most derived genus. These results are also consistent with Leclerc et al. (1998) in that $F$. serratus is basal to the remaining Fucus species, although none of the spe- cies that our study indicates as sister to $F$. serratus was sampled in their study.

Fucus is monophyletic, and all species of Fucus are closely related. The well-supported (Fig. 3) clustering of $F$. spiralis (monoecious), F. virsoides (monoecious), $F$. vesiculosus (dioecious), and $F$. ceranoides (dioecious) indicates that these are closely related and contradicts expectations that all monoecious versus dioecious species of Fucus diverged early in the evolutionary history of the Fucaceae (Powell 1963; Fig. 1). Further evidence against an early di- 


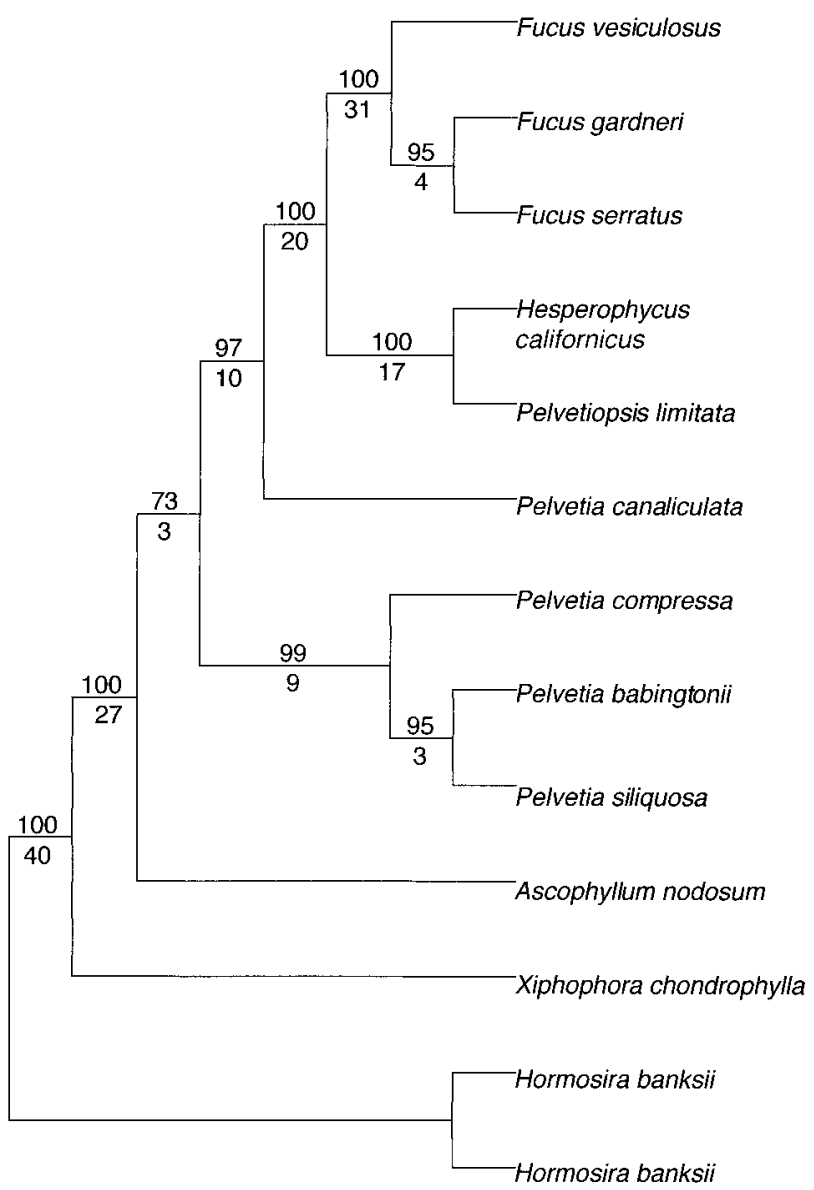

FIG. 4. The single most parsimonious tree for the ITS region of the taxa selected for the final analyses. Bootstrap (above) and decay (below) support values for the clades are indicated.

vergence of dioecious versus monoecious species comes from the fact that $F$. serratus, which is dioecious and has thus been assumed to be more closely related to $F$. vesiculosus, appears in the same lineage that gave rise to monoecious species: $F$. distichus, $F$. evanescens, and F. gardneri. Our results (Fig. 3) suggest that these might not be monophyletic species. These were once classified as a single species with several subspecies that differed in morphology and habitat (Powell 1957). Although F. distichus and $F$. evanescens are very closely related, they are reproductively isolated to a large degree, at least in New England, because their reproductive seasons do not overlap to a great extent and especially because reproduction in $F$. distichus occurs in tide pools at low tide (Pearson and Brawley 1996), when the chance of cross-fertilization with the low-shore species $F$. evanescens is reduced. Fucus gardneri might be reproductively isolated from these because it occurs only in the eastern Pacific Ocean, although ITS sequences suggest that $F$. evanescens from Japan might be more related to $F$. gardneri than to Atlantic $F$. evanescens.

The character "monoecious/dioecious" has

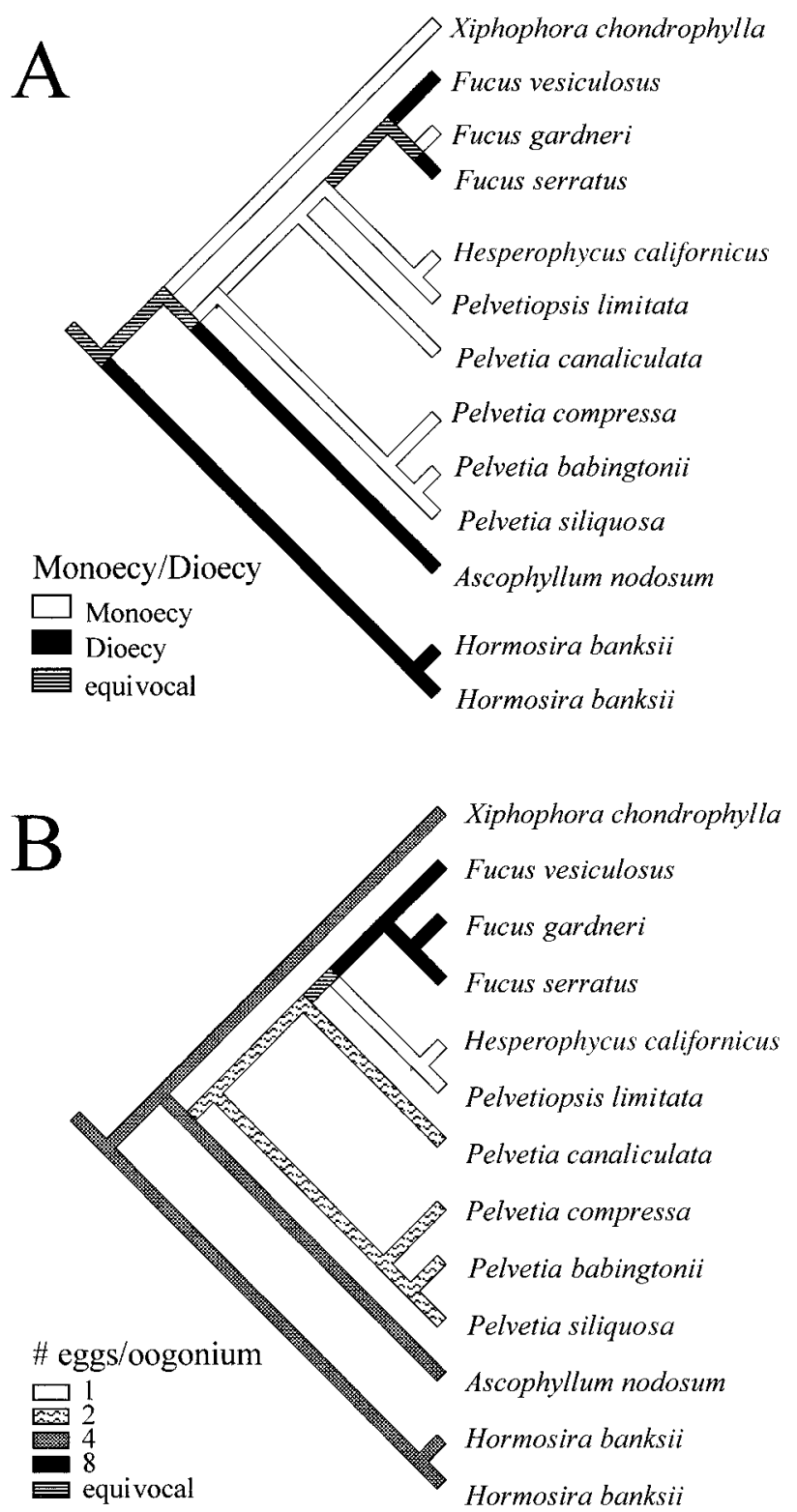

FIG. 5. Evolution of the characters (A) monoecy/dioecy and (B) number of eggs per oogonium in the Fucaceae as inferred from sequences of the ITS region.

changed several times during the evolutionary history of the Fucaceae (Fig. 5A), and the same was found in Desmarestiaceae (Peters et al. 1997). This suggests that in brown algae, monoecy/dioecy can be changed by relatively simple mechanisms and thus is not a good indicator of evolutionary relationships. The monoecious condition might have been more favorable to rapid, long-distance migration of small populations because the Fucaceae do not produce vegetative propagules. For effective dispersal of dioecious species that reproduce only sexually, it is necessary that enough individuals of both sexes are present for sexual reproduction to occur with the high rates of success that have been observed in fu- 
coid populations (Brawley 1992, Pearson and Brawley 1996, Serrão et al. 1996).

The phylogeny based on ITS sequences does not support the hypothesis (Fritsch 1945, Powell 1963; Fig. 1) that producing eight eggs per oogonium is the most primitive state in Fucaceae. However, this character seems to have evolved mostly in the direction of a progressive reduction in the number of viable eggs produced per oogonium, Fucus being the only exception (Fig. 5B). The inclusion of Hesperophycus and Pelvetiopsis in the same clade suggests that the character state "producing one egg per oogonium" evolved only once, in the common ancestor to these genera, also contradicting Powell's (1963) hypothesis (Fig. 1). Thus, although the character egg number does not follow the trend suggested by Powell (1963), it seems to be a useful character to distinguish the clades revealed by the ITS data.

The placement of Xiphophora as sister to the northern hemisphere Fucaceae is supported by ITS data. Xiphophora has unusual features for the Fucaceae, and Clayton (1984) has suggested that its evolutionary history should be further investigated. Xiphophora lacks clearly defined receptacles, a characteristic in common with Hormosira. The sperm of Xiphophora have different features from the sperm of northern hemisphere Fucaceae (Clayton 1994). Instead, they share structural similarities with the monotypic families Hormosiraceae and Himanthaliaceae (Clayton 1994), especially the possession of a spine on the anterior flagellum of the sperm (Moestrup 1982). This has been used as a basis to propose that the genera Xiphophora, Hormosira, and Himanthalia might be related (Moestrup 1982), a hypothesis that warrants further investigation of the evolutionary history of Himanthalia. On the other hand, the fucacean characteristics of Xiphophora are dichotomous branching and a four-sided apical cell (Clayton 1984). Sperm ultrastructure (Manton 1964, 1965) suggests that the Cystoseiraceae are a primitive state and that Fucus represents the most advanced condition. Hormosira (Hormosiraceae) seems related to Xiphophora (Fucaceae) on the basis of sperm ultrastructure (Manton 1965) and the absence of true receptacles but not on the basis of other characteristics. However, the character "apical cell" suggests that the Seirococcaceae might be the most related family to the Fucaceae, as both have a four-sided apical cell (Clayton 1984), although another character (one single mature egg produced per oogonium) suggests that the Seirococcaceae might be more closely related to the Cystoseiraceae instead (Clayton 1984). Given this controversy, we attempted to include representatives of all three of these families (Hormosira (Hormosiraceae), Cystosphaera (Seirococcaceae), and Cystoseira and Bifurcaria, both Cystoseiraceae) in the outgroup, but only Hormosira was alignable in the ITS region, suggesting that it is the closest relative of Fucaceae.
The intraindividual variability in the ITS region of Fucus species and the occurrence of shared interspecific polymorphisms in each of the two unresolved clusters of Fucus species might be a consequence of gene flow between species through frequent hybridization and/or rapid recent radiation at a rate that exceeds the homogenization rate by concerted evolution (Hillis and Davis 1988, Williams et al. 1988). The latter is consistent with the fact that low intraindividual variability was found in A. nodos$u m$, a basal genus. The hybridization hypothesis is supported by the fact that sequences from an individual $F$. vesiculosus might be more similar to ITS sequences from $F$. spiralis than to other sequences from that same individual. Fucus species can be cross-fertilized in the laboratory (Thuret 1854, Williams 1899, Kniep 1925, Burrows and Lodge 1953, Bolwell et al. 1977, Edwards et al. 1997), and numerous reports exist of the occurrence of putative Fucus hybrids in nature (Sauvageau 1909, Stomps, 1911, Kniep 1925, Burrows and Lodge 1951, Scott and Hardy 1994). The only species in this cluster that cannot hybridize with the others in nature is the Mediterranean-endemic Fucus virsoides because it is geographically isolated from all other Fucaceae.

How can these results help explain the bipolar distribution of the Fucaceae? Also, if the Fucaceae originated in southern Australia, where the Fucales seem to have evolved and diversified (Clayton 1984), when and through which route did they colonize the northern Pacific and Atlantic Oceans while remaining absent from South America and most of Africa (except for Fucus in northern Morocco and the Canary Islands)?

If sequence divergence and divergence time are correlated in this data set, the large divergence in ITS sequences (Table 2) between the Fucaceae of the southern and northern hemispheres indicates that these have been isolated for a long period. An ancient separation of these cold-adapted seaweeds could be the result of 1) a transequatorial crossing during a colder period or 2) cold adaptation and consequent hemispheric divergence of an ancestor that might have been initially adapted to the warmer conditions of lower latitudes. The first of these hypotheses seems to be more likely because it is consistent with the hypothesis that the order Fucales evolved and radiated during the Mesozoic on the southern shores of Australasia (Clayton 1984). This is supported by the fact that genera from all but one (Himanthaliaceae) of the families of Fucales occur there, and those have characteristics that are considered primitive in each family (Clayton 1984). Thus, the most likely origin for the evolution of the $\mathrm{Fu}-$ caceae might be in Australia, where a Fucaceae ancestor common to Xiphophora and to the northern Fucaceae might have been able to colonize or drift across the equatorial fringe, invading the Pacific, during a cooler period. A similar southern hemisphere ancient origin followed by a transequatorial 
crossing is suggested by ITS sequences in the Desmarestiaceae (Peters et al. 1997).

Clayton (1984) suggests that the opportunity for the early fucoids to migrate to the northern hemisphere might have been provided by the Pleistocene glaciations (2 Myr to 18,000 years ago), when the ocean's temperatures had decreased significantly and a land bridge existed between Australia and Indonesia (Clayton 1984). However, the large sequence distances between Xiphophora and the northern Fucaceae suggest that their divergence would have started before this period, perhaps during the Oligocene/Miocene (38-7 Myr ago). In comparison, sequence divergence was very low in the ITS region of Arctic and Antarctic species of a brown algal genus hypothesized to have been isolated since the Pleistocene glaciations (van Oppen et al. 1993). Alternatively, the levels of divergence observed in this DNA region of the Fucaceae might not be proportional to the evolutionary time since divergence. This could have been the case if rapid speciation events occurred in a short time, when possibly small populations of Fucaceae might have spread through the very hostile and thus very selective intertidal regions.

After the northern Fucaceae became isolated from the southern hemisphere ones, ancestors to $A$. nodosum and $P$. canaliculata might have invaded the Atlantic, where they acquired the endophytic fungus Mycosphaerella. However, if this took place through crossing the Arctic, it would have been possible only 3-3.5 Myr ago, when the Bering Strait opened (e.g. Lüning 1990, Vermeij 1991, Dunton 1992) ${ }^{5}$. The opening of the Bering Strait, which had been closed for approximately $60 \mathrm{Myr}$, was followed by several events of opening and closing of this connection between the Pacific and the Atlantic by way of the Arctic. These events might have been involved in the origin of the divergence between ancestors to Fucus and Hesperophycus/Pelvetiopsis and later between Pacific and Atlantic Fucus. The western Atlantic shores lack $P$. canaliculata and $F$. serratus is present only in a restricted area, probably as a species introduced there from Europe by humans in the 1800s (Robinson 1903, Edelstein et al. 1971-73). These shores might have been secondarily colonized by the Fucaceae following the glaciated periods when coldadapted rocky shore species, forced to migrate south, might have found suitable rocky intertidal shores on the eastern Atlantic but not on the western Atlantic (Lüning 1990, Palumbi and Kessing 1991). Secondary recolonization of the western Atlantic following the Pleistocene glaciations has also

\footnotetext{
${ }^{5}$ Note in proof: L. Marincovich and A. Y. Gladenkov (1999, Evidence for an early opening of the Bering Strait. Nature 397: 149-151) present data in support of the first opening of the Bering Strait occurring between 4.8-7.4 Myr. This is in agreement with our sequence data suggesting that the colonization of the Atlantic by the Fucaceae took place earlier than the data previously estimated for the first opening of the Bering Strait.
}

been suggested for other macroalgae (e.g. Lüning 1990, van Oppen et al. 1995).

The geographic distribution of all but one of the Fucus species in the Atlantic and its adjacent seas, and the fact that the only Pacific-endemic species (F. gardneri) is not basal for the genus, suggests that Fucus evolved in the northern Atlantic Ocean and only later colonized the Pacific. Thus, the evolution of Fucus gardneri in the Pacific might be associated with a transarctic passage of an Atlantic ancestor common to $F$. serratus and $F$. gardneri, although most transarctic crossings documented for marine animals (e.g. Palumbi and Kessing 1991, Vermeij 1991) and macroalgae (e.g. Stam et al. 1988, van Oppen et al. 1994, 1995) occurred from the Pacific to the Atlantic. Fucus distichus and F. evanescens (if indeed they represent species that are distinct from each other and from $F$. gardneri) might have evolved in the Arctic, given their current climatic affinities to cold regions. The Pacific populations of $F$. spiralis that we used in this study seem to be recent and are probably an example of human-mediated dispersal.

Powell (1963) proposed that the Mediterranean $F$. virsoides is derived from a common ancestor with $F$. spiralis because they are both monoecious and morphologically similar. The simplest explanation for the presence of $F$. virsoides in the Mediterranean, where no other Fucaceae are currently present, is that Fucus might have occurred throughout the Mediterranean during the last glaciation event, having been eliminated from most of the Mediterranean as glaciation ended. A small population would have survived in the Adriatic Sea and, being geographically isolated from the remaining population, diverged into what is now $F$. virsoides.

In conclusion, the phylogeny based on ITS and its flanking sequences in nrDNA argues against the well-established model for phylogenetic relationships in the Fucaceae proposed by Powell (1963). Major conclusions are the following: 1) The Fucaceae appear monophyletic, but the genera from the northern hemisphere are considerably divergent from Xiphophora. Thus, removing this genus from the family is a possibility that deserves consideration. 2) Pelvetia is not monophyletic. We propose that $\mathrm{Pel}$ vetia should be a monotypic genus consisting of $P$. canaliculata and establish a new genus (below) for the Pacific taxa presently included in Pelvetia. 3) The monotypic genus Ascophyllum is sister to the other northern hemisphere Fucaceae. 4) The monotypic genera Hesperophycus and Pelvetiopsis form a monophyletic lineage (N. B. Gardner 1910). 5) Fucus is monophyletic and comprises two major lineages: one including $F$. vesiculosus, $F$. spiralis, $F$. ceranoides, and $F$. virsoides and the other including $F$. serratus as sister to $F$. evanescens, $F$. distichus, and $F$. gardneri. 6) Sequences of the ITS region are not useful to infer phylogenetic relationships within each of these two Fucus subclades, possibly because of hybridization and/or incomplete concerted evolution. However, 
the results suggest that some of these might not be monophyletic and/or that hybridization might occur between some species within each cluster. 7) During evolution of the Fucaceae, the character number of eggs per oogonium has not followed a gradual reduction. The character monoecy/dioecy has changed several times, thus having little value in defining evolutionary relationships in the family.

We transfer Pelvetia babingtonii (Harvey) De Toni, P. compressa (J. Agardh) De Toni, and P. siliquosa Tseng et C. F. Chang to Silvetia, gen. nov. This transfer is based upon anatomical differences and our molecular analysis of the species presently included in Pelvetia.

Silvetia E. Serrão T. O. Cho, S. M. Boo et Brawley, gen. nov.

Diagnosis: Novum genus Fucaceae plerumque ovis cum duobus per oogonium. Verbum ipsum Pelvetiae simile est, sed etiam dissimile putandum est propter divisionem quandam oogoniorum potius in longitudinem vel in obliquitatem quam ex transverso perductam; propter varietatem quandam in ipso ordine quo aciditas nuclei cum signis de rDNA inter se transcriptis complectitur.

New genus of the Fucaceae, typically with 2 eggs per oogonium, similar in morphology to Pelvetia but distinguished from it by cleavage of the oogonia being longitudinal or oblique, as opposed to transverse; by differences in the nucleic acid sequence of the internal transcribed spacers (ITS-1, ITS-2) of the rDNA.

Type species: Silvetia compressa (J. Agardh) E. Serrão, T. O. Cho, S. M. Boo et Brawley, comb. nov.

Basionym: Fucoidium compressum J. Agardh (Sp. Alg. 1:204. 1848)

Etymology: Named in honor of Paul C. Silva, a keen student of the fucoid algae and Curator of Algae at the Herbarium of the University of California at Berkeley.

We also propose the following new combinations:

Silvetia babingtonii (Harvey) E. Serrão, T. O. Cho, S. M. Boo et Brawley, comb. nov.

Basionym: Fucus babingtonii Harvey (Proc. Amer. Acad. Arts EO Sci. 4:329. 1860).

Silvetia siliquosa (Tseng \& C. F. Chang) E. Serrão, T. O. Cho, S. M. Boo et Brawley, comb. nov.

Basionym: Pelvetia siliquosa Tseng \& C. F. Chang (Acta Bot. Sin. 2:293. 1953).

The oogonia of the species that we transfer to Silvetia typically cleave longitudinally or slightly obliquely (Yendo 1907, Gardner 1910, Tseng and Chang 1953), rather than transversely as in Pelvetia canaliculata (e.g. Fritsch 1945). Cleavage is irregular if more than the typical 2 eggs per oogonium are produced (Gardner 1910, Tseng and Chang 1983,
Song et al. 1996). Similar abnormalities in egg number and cleavage are observed, in a small number of oogonia in most Fucaceae (pers. obs.). These variations may result from defective cleavage and/or an abnormal targeting of the number of haploid nuclei retained in the young oogonium (see Fritsch 1945). Both Pelvetia and Silvetia include perennial fucacean algae that lack a midrib and are found in the upper intertidal zone, but those taxa transferred here to Silvetia tend to be more cartilaginous than Pelvetia. Ecotypic factors contribute to variations in how cartilaginous the various species of Silvetia are and to their stature (Yoshida and Silva 1992, Song et al. 1996). Silva (1996) includes a photograph (his Fig. 3, showing Fucus compressus C. Agardh) of an isotype of Fucoidium compressum and provides related discussion. Molecular phylogenetic analysis has demonstrated that the oogonial plane of division is a robust character (cf. Yendo 1907).

Advice from Dr. Debashish Bhattacharya was invaluable to us. We are also grateful for helpful comments on an earlier draft by Dr. Irv Kornfield, to Dr. Jeanine Olsen, and for the comments by two anonymous reviewers and Dr. Wytze Stam that greatly improved the manuscript. Many thanks to Dr. Christopher Campbell for use of his equipment, to Patty Singer and Dr. Diane Caporale for running the automated sequencer, to Dr. Gareth Pearson for general help, and to all who collected and mailed specimens: Dr. Kathryn van Alstyne (Oregon), Dr. Christine Ashburner (Australia), Dr. Jon Ashen (California), Dr. Mauro Bastianini (Venice), Dr. Carolyn Bird (Nova Scotia), Dr. Vanda Brotas (South Portugal), Dr. Ian Davison (Antarctic), Dr. Megan Dethier (Washington State), Dr. D. L. Duan (China), Ben Hale (California), Dr. Ricardo Haroun (Canary Islands), Jenny Hedman (Norway and northern Sweden), Dr. Joanna Jones (Isle of Man), Dr. Lena Kautsky (southern Sweden), Dr. Erin Krellwitz (North Carolina), Rhoda Lin (California), Marina Lipizer (Trieste), Dr. Arthur Mathieson (New Hampshire), Joe McIntyre (northern Sweden), Dr. Taizo Motomura (Japan), Dr. Isabel Pinto (northern Portugal), and Dr. Rui Santos (Algarve) and Dr. Richard Searles (North Carolina), Dr. Dagmar Stengel (Galway), Brian Wysor (Long Island), and the staff of the Kartesh Marine Station of the University of St. Petersburg for help during collecting trips in the White Sea, Russia. We appreciate nomenclatural advice from Drs. Michael Guiry, Christine Maggs, Richard Moe and an anonymous referee and thank Estelle Sheehan for the Latin diagnosis. We appreciate the collaboration of Tae Oh Cho and Dr. Sung Min Boo (Chungnam National University) in the diagnosis; they will present additional work elsewhere. This study was supported by the NSF grant OCE-9216981 to S.H.B. and by a bequest of H. Franklin Brawley. E.A.S. is also thankful for graduate fellowships from the Fulbright Commission, JNICT (Portugal), the LusoAmerican Foundation, and the Center for Marine Studies-Sea Grant of Maine/New Hampshire (U.S.A.).

Bakker, F. T., Olsen, J. L. \& Stam, W. T. 1995a. Evolution of nuclear rDNA ITS sequences in the Cladophora albida/sericea Clade (Chlorophyta). J. Mol. Evol. 40:640-51.

Bakker, F. T., Stam, W. T. \& Olsen, J. L. 1995b. Global phylogeography in the cosmopolitan species Cladophora vagabunda (Chlorophyta) based on nuclear rDNA ITS sequences. Eur. J. Phycol. 30:197-208.

Baldwin, B. G., Sanderson, M. J., Porter J. M., Wojciechowski, M. F., Campbell, C. S. \& Donoghue, M. J. 1995. The ITS region of nuclear ribosomal DNA: a valuable source of evidence on angiosperm phylogeny. Ann. Missouri Bot. Garden 82:247-77. 
Bolwell, G. P., Callow, J. A., Callow, M. E. \& Evans, L. V. 1977. Cross-fertilization in fucoid seaweeds. Nature 268:626-7.

Brawley, S. H. 1992. Fertilization in natural populations of the dioecious brown alga Fucus ceranoides L. and the importance of the polyspermy block. Mar. Biol. 113:145-57.

Bremer, K. 1988. The limits of amino acid sequence data in angiosperm phylogenetic reconstruction. Evolution 42:795-803.

Burrows, E. M. \& Lodge, S. M. 1951. Autecology and the species problem in Fucus. J. Mar. Biol. Assoc. UK 30:161-76.

1953. Culture of Fucus hybrids. Nature 172:1009-10.

Clayton, M. N. 1984. Evolution of the Phaeophyta with particular reference to the Fucales. In Round, F. E. \& Chapman, D. J. [Eds.] Progress in Phycological Research, vol. 3. Biopress, Bristol, pp. 11-46.

1994. Circumscription and phylogenetic relationships of the southern hemisphere family Seirococcaceae (Phaeophyceae). Bot. Mar. 37:213-20.

Coleman, A. W., Suarez, A. \& Goff, L. J. 1994. Molecular delineation of species and syngens in Volvocacean green algae (Chlorophyta). J. Phycol. 30:80-90.

Decaisne, J. \& Thuret, G. 1845. Recherches sur les antheridies et les spores de quelques Fucus. Ann. Sci., Ser. 3, Bot. 3:1-15.

Donoghue, M. J., Olmstead, R. G., Smith, J. F. \& Palmer, J. D. 1992. Phylogenetic relationships of Dipsacales based on rbcL sequences. Ann. Missouri Bot. Garden 79:333-45.

Doyle, J. J. \& Doyle, J. L. 1987. A rapid DNA isolation procedure for small quantities of fresh leaf tissue. Phytochem. Bull. 19: 11-5.

Dunton, K. 1992. Arctic biogeography: the paradox of the marine benthic fauna and flora. TREE 7:183-9.

Edelstein, T., M. Greenwell, C. J. Bird \& J. McLachlan. 1971-73. Investigations of the marine algae of Nova Scotia. X. Distribution of Fucus serratus L. and some other species of Fucus in the maritime provinces. Proc. Nova Scotia Inst. of Science. 27, $33-42$.

Edwards, G. O., Callow, J. A. \& Brownlee, C. 1997. Cross-fertilization in Fucus: a molecular approach. Phycologia 36(Suppl.): 28.

Eriksson, T. \& Wikstrom, N. 1996. AutoDecay, Version 3.0. Distributed by the authors, Stockholm University, Sweden.

Felsenstein, J. 1985. Confidence limits on phylogenies: an approach using the bootstrap. Evolution 39:783-91.

Fritsch, F. E. 1945. The Structure and Reproduction of the Algae, vol. 2. Cambridge University Press, London.

Gard, M. 1910. Sur un hybride des Fucus platycarpus et Fucus ceranoides. Comptes Rendus l'Acad Sci Paris 151:888-90.

Gardner, N. L. 1910. Variation in nuclear extrusion among the Fucaceae. Univ. Calif. Publ. Bot. 4:121-36.

Goff, L. J., Moon, D. A. \& Coleman, A. W. 1994. Molecular delineation of species and species relationships in the red algal agarophytes Gracilariopsis and Gracilaria (Gracilariales). J. Phycol. 30:521-37.

Hamby, R. K. \& Zimmer, E. A. 1992. Ribosomal RNA as a phylogenetic tool in plant systematics. In Soltis, P. S., Soltis, D. E. \& Doyle, J. J. [Eds.] Molecular Systematics of Plants. Chapman and Hall, New York, pp. 50-91

Hillis, D. M. 1991. Discriminating between phylogenetic signal and random noise in DNA sequences. In Miyamoto, M. M. \& Cracraft, J. [Eds.] Phylogenetic Analysis of DNA Sequences. Oxford University Press, New York, pp. 278-94.

Hillis, D. M., Allard, M. W. \& Miyamoto 1993. Analysis of DNA sequence data: phylogenetic inference. In Zimmer, E. A. [Ed.] Methods in Enzymology. Vol. 224: Molecular Evolution: Producing the Biochemical Data. Academic Press, San Diego, pp. 456-87.

Hillis, D. M. \& Davis, S. K. 1988. Ribosomal DNA: intraspecific polymorphism, concerted evolution, and phylogeny reconstruction. Syst. Zool. 37:63-6.

Hillis, D. M. \& Huelsenbeck J. P. 1992. Signal, noise, and reliability in molecular phylogenetic analyses. J. Hered. 83:18995.

Kalvas, A. \& Kautsky, L. 1993. Geographical variation in Fucus vesiculosus morphology in the Baltic and North Seas. Eur. J. Phycol. 28:85-91.

Kniep, H. 1925. Ueber Fucus bastarde. Flora 118:331-8.

Knight, M. \& Parke, M. 1950. A biological study of Fucus vesiculosus L. and F. serratus L. J. Mar. Biol. Assoc. UK 29:439-514.

Kohlmeyer, J. \& Kohlmeyer, E. 1979. Marine Mycology. Academic Press, New York, 690 pp.

Kooistra, W. H. C. F., Olsen, J. L., Stam, W. T. \& Hoek, C. van den. 1992. Biogeography of Cladophoropsis membranacea (Chlorophyta) based on comparisons of nuclear rDNA ITS sequences. J. Phycol. 28:660-8.

Leclerc, M. C., Barriel, V., Lecointre, G. \& de Reviers, B. 1998. Low divergence in rDNA ITS sequences among five species of Fucus (Phaeophyceae) suggests a very recent radiation. $J$. Mol. Evol. 46:115-20.

Lee, W. J., Yoon, H. S. \& Boo, S. M. 1998. Phylogenetic relationships of Pelvetia and Pelvetiopsis (Phaeophyceae) based on small subunit ribosomal DNA sequences. J. Plant Biol. 41:103-9.

Lüning, K. 1990. Seaweeds: Their Environment, Biogeography and Ecophysiology. J. Wiley, New York, $527 \mathrm{pp}$.

Maddison, W. P. \& Maddison, D. R. 1992. MacClade, Version 3.0. Sinauer, Sunderland, Massachusetts.

Manton, I. 1964. A contribution towards understanding of "the primitive fucoid." New Phytol. 63:244-52.

1965. Some phyletic implications of flagellar structure in plants. In Preston, R. [Ed.] Advances in Botanical Research, Academic Press, London, pp. 1-34.

Moestrup, Ø. 1982. Flagellar structure in algae: a review, with new observations particularly on the Chrysophyceae, Phaeophyceae (Fucophyceae), Euglenophyceae, and Reckertia. Phycologia 2:427-528.

Niell, F. X., Miranda, A. \& Pazó, J. P. 1980. Studies on the morphology of the megaecade limicola of Fucus vesiculosus L. with taxonomical comments. Bot. Mar. 23:303-7.

Palumbi, S. R. \& Kessing, B. D. 1991. Population biology of the trans-Arctic exchange: mtDNA sequence similarity between Pacific and Atlantic sea urchins. Evolution 45:1790-1805.

Pearson, G. A. \& Brawley, S. H. 1996. Reproductive ecology of Fucus distichus (L.): an intertidal alga with successful external fertilization. Mar. Ecol. Prog. Ser. 143:211-23.

Pérez-Ruzafa, I., Gallardo, T. \& Gómez-Cancio, R. 1993. Numerical taxonomy of some taxa of the genus Fucus in the Iberian Peninsula. Hydrobiology 260/261:81-90.

Peters, A., van Oppen, M. J. H., Wiencke, C., Stam, W. T. \& Olsen, J. L. 1997. Phylogeny and historical ecology of the Desmarestiaceae (Phaeophyceae) support a southern hemisphere origin. J. Phycol. 33:294-309.

Powell, H. T. 1957. Studies in the genus Fucus L. I. Fucus distichus L. emend. Powell. J. Mar. Biol. Assoc. UK 36:407-32.

1963. Speciation in the genus Fucus L., and related genera. Syst. Assoc. Publ. 5:63-77.

Rice, E. L. \& Chapman, A. R. O. 1985. A numerical taxonomic study of Fucus distichus (Phaeophyta). J. Mar. Biol. Assoc. UK 65:433-59.

Robinson, C. B. 1903. The distribution of Fucus serratus in America. Torreya 13, 132-34.

Rousseau, F., Leclerc, M. C. \& de Reviers, B. 1997. Molecular phylogeny of European Fucales (Phaeophyceae) based on partial large-subunit rDNA sequence comparisons. Phycologia 6:438-46.

Saunders, G. W. \& Druehl, L. D. 1993. Nucleotide sequences of the internal transcribed spacers and 5.8S rRNA genes from Alaria marginata and Postelsia palmaeformis (Phaeophyta: Laminariales). Mar. Biol. 115:347-52.

Sauvageau, C. 1909. Sur l'hybride des Fucus vesiculosus et Fucus serratus. Comptes Rendus Soc. Biol. Paris 67:832-3.

Scott, G. W. \& Hardy, F. G. 1994. Observations of the occurrence of hybrids between two sympatric species of fucoid algae. Cryptogamie, Algol. 15:297-305.

Serrão, E. A. 1996. Reproductive biology of Fucus vesiculosus L. in the Baltic Sea. Ph.D. thesis, University of Maine, Orono, 172 $\mathrm{pp}$

Serrão, E. A. \& Brawley, S. H. 1997. Phylogeny of the Fucaceae 
based on DNA sequences of rRNA-ITS. Phycologia 36(Suppl.): 101.

Serrão, E. A., Pearson, G. A., Kautsky, L. \& Brawley, S. H. 1996. Successful external fertilization in turbulent environments. Proc. Natl. Acad. Sci. USA 93:5286-90.

Silva, P. C. 1996. California seaweeds collected by the Malaspina Expedition, especially Pelvetia (Fucales, Phaeophyceae). Madroño 43:345-54.

Song, H. S., Seo, K. S. \& Boo, S. M. 1996. Field studies of the brown alga Pelvetia siliquosa with implications for taxonomy and distribution. Algae 11:65-71.

Stache-Crain, B., Müller, D. G. \& Goff, L. J. 1997. Molecular systematics of Ectocarpus and Kuckuckia (Ectocarpales, Phaeophyceae) inferred from phylogenetic analysis of nuclear- and plastid-encoded DNA sequences. J. Phycol. 33:152-68.

Stam, W. T., Bot, P. V. M., Boele-Bos, S. A., van Rooij, J. M. \& van den Hoek, C. 1988. Single-copy DNA-DNA hybridizations among five species of Laminaria (Phaeophyceae): phylogenetics and biogeographic implications. Helgoländer Meeresunters. 42:251-67.

Stomps, T. J. 1911. Études topographiques sur la variabilite des Fucus vesiculosus L., platycarpus Thur., et ceranoides L. Recueil l'Instit Bot 'Leo Errera' Brux. 8:326-77.

Swofford, D. L. 1998. PAUP (Phylogenetic Analysis Using Parsimony), Version 4.0b1. Sinauer, Sunderland, Massachusetts.

Thuret, G. 1854. Recherches sur la fécondation des Fucacées. Ann. Sci. Nat. Bot. série 4, 2:197-214.

Tseng, C. K. \& C. F. Chang. 1953. On a new species of Pelvetia and its distribution. Acta Bot. Sinica 2:280-97.

van Oppen, M. J. H., Olsen, J. L., Stam, W. T., Hoek, C. van den
\& Wiencke, C. 1993. Arctic-Antarctic disjunctions in the benthic seaweeds Acrosiphonia arcta (Chlorophyta) and Desmarestia viridis/willii (Phaeophyta) are of recent origin. Mar. Biol. 115:381-6.

van Oppen, M. J. H., Diekmann, O. E., Wiencke, C., Stam, W. T. \& Olsen, J. L. 1994. Tracking dispersal routes: phylogeography of the Arctic-Antarctic disjunct seaweed Acrosiphonia arcta (Chlorophyta). J. Phycol. 30:67-80.

van Oppen, M. J. H., Draisma, S. G. A., Olsen, J. L. \& Stam, W. T. 1995. Multiple trans-Arctic passages in the red alga Phycodrys rubens: evidence from nuclear rDNA ITS sequences. Mar. Biol. 123:179-88.

Vermeij, G. J. 1991. Anatomy of an invasion: the trans-Arctic interchange. Paleobiology 17:281-307.

White, T. J., Burns, T., Lee, S. \& Taylor, J. 1990. Amplification and direct sequencing of fungal ribosomal RNA genes for phylogenetics. In Innis, M., Gelfand, D., Sninsky, J. \& White, T. [Eds.] PCR Protocols: A Guide to Methods and Applications. Academic Press, San Diego, pp. 315-22.

Williams, J. L. 1899. New Fucus hybrids. Ann. Bot. 13:187-8.

Williams, S. C., DeBry, R. W. \& Feder, J. L. 1988. A commentary on the use of ribosomal DNA in systematic studies. Syst. Zool. 37:60-2.

Wynne, M. J. \& Magne, F. 1991. Concerning the name Fucus muscoides (Cotton) J Feldmann et Magne. Cryptogamie, Algol. 12: $55-65$.

Yendo, K. 1907. The Fucaceae of Japan. J. Coll. Sci. Imp. Univ. Tokyo 21:1-174.

Yoshida, T. \& P. C. Silva. 1992. On the identity of Fucus babingtonii Harvey (Fucales, Phaeophyta). Japan. J. Phycol. 40:121-24. 